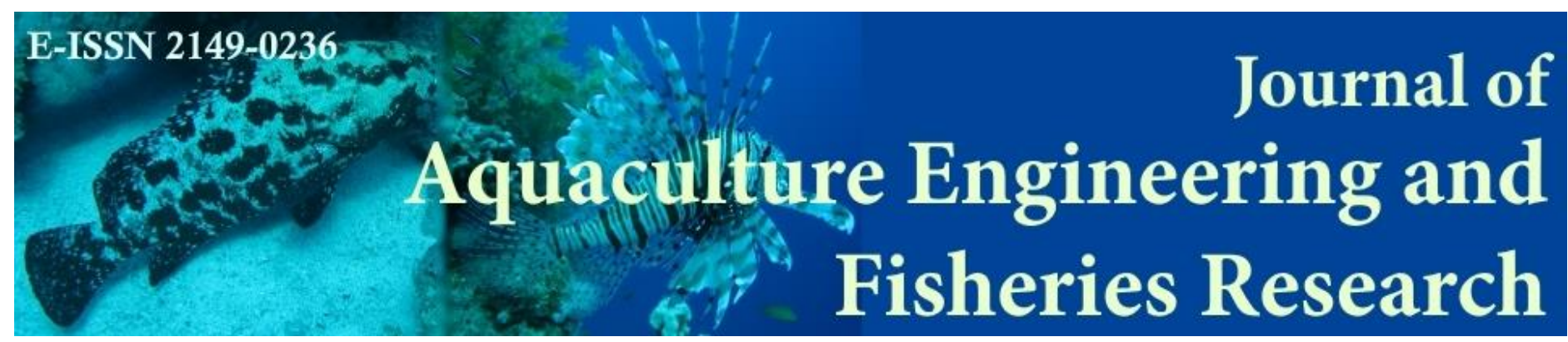

FULL PAPER

TAM MAKALE

\title{
A STUDY ON AWARENESS OF PEOPLE ABOUT JELLYFISH ALONG THE SOUTHWEST COASTS OF TURKEY
}

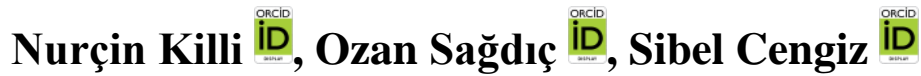

Cite this article as:

Killi, N., Sağdıç, O., Cengiz, S. (2018). A Study on Awareness of People About Jellyfish Along The Southwest Coasts of Turkey. Journal of Aquaculture Engineering and Fisheries Reaserch, 4(1), 55-63. DOI: 10.3153/JAEFR18006

Muğla Sitkı Koçman University, Faculty of Fisheries, Department of Hydrobiology, Muğla-Turkey

Submitted: 03.05.2017

Accepted: 26.12 .2017

Published online: 28.12 .2017

Correspondence:

Nurçin KILLI

E-mail: ngulsahin@mu.edu.tr

Journal of Aquaculture Engineering and Fisheries Research

E-ISSN 2149-0236

4(1), 55-63 (2018)

DOI: 10.3153/JAEFR18006

ScientificWebJournals (SWJ) (C)2015-2018

\begin{abstract}
This study is about a questionnary developed to collect data related awareness of people about jellyfish and injury cases. The questionnary was distributed to 226 people in the touristic areas of the west and the southwest regions of Turkey, with the participants consisting of holiday-makers, people working in the tourism sector, fishermen, divers as well as local dwellers. Overall, $78 \%$ of the participants had previous awareness of the existence of jellyfish, whereas the remaining $22 \%$ had heard about jellyfish for the first time only. The most known jellyfish species were Aurelia aurita, Cotylorhiza tuberculata, Chrysaora hysoscella and Rhizostoma pulmo. In total, $42 \%$ of the participants had run into jellyfish at least on one occasion before. The most common injuries were erythema, itching and blistering, and two people retained scars caused by Pelagia noctiluca. Of the participants that were injured by jellyfish, $91 \%$ did not seek hospitalisation or health care, $76 \%$ were unaware of the measures necessary following jellyfish injury, and $96 \%$ of those who spotted jellyfish whilst swimming or from the beach did not inform any academic institution or research organisation. Since jellyfish form swarms that are usually carried around randomly by currents, it is mandatory that people be informed about jellyfish blooms and possible related injuries. This is especially important since jellyfish injury cases are generally not being recorded from hospitals and health care providers throughout Turkey. The present questionnary-based study has shown that even people affected by jellyfish injuries fail to notify relevant institutes or organisations. Further questionnaries and related projects should be implemented so as to collect data of jellyfish injuries and to increase people's awareness of jellyfish-related risks in other parts of Turkey.
\end{abstract}

Keywords: Questionnary-based study, Local ecological knowledge, Medusae, Injury, Jellyfish bloom 


\section{Introduction}

Jellyfish blooms are often observed around the world. Coastal aggregations of jellyfish have become a serious problem for the bathers on the coasts. Jellyfish stings threaten on human health by toxic and allegic reactions (Burnett, 2001; Fenner, 1998; Mariottini and Pane, 2010). In Australia, many people effect by stings of the Irukandji species every year even fatal cases are seen every 3-4 years (Gershwin et al., 2013). Mediterranean jellyfish species are not lethal but some species for example Physalia physalis, Rhopilema nomadica, Carybdea marsupialis and Pelagia noctiluca can cause serious problems on human (Mariottini and Pane, 2010). From these species only $R$. nomadica and $P$. noctiluca distribute in Turkey seas. $P$. physalis sting causes severe pain and urticarial on humans (Lin and Hessinger, 1979). Many injury cases by $P$. physalis were reported in French coasts in 2008, 2010 and 2011 (Labadie et al., 2012). C. marsupialis which was recorded from Aegean coasts of Turkey (Çınar et al., 2014) venom effects on human skin and causes severe pain, burning sensation, erythematous vesicular eruption and local oedema (Kokelj et al., 1992; Milla et al., 2000; Sanchez-Rodriguez et al., 2006). Also this species consumes zooplankton and ichthyoplankton and effects on fish populations directly and indirectly (Larson, 1976; Nogueira Jr and Haddad, 2008; Bordehore et al., 2011). According to Gordoa et al. (2013) $P$. noctiluca has predation capacity on Atlantic Bluefin Tuna eggs. Also this species which can cause erythema, edema, itching, burning, vesicles and severe pain in the skin (Scarpa, 1984; 1987; Kokelj and Burnett, 1988; Carli et al., 1991; Carli et al., 1995) is the most dangerous native Mediterranean jellyfish (UNEP, 1984). $R$. nomadica which has injured holiday makers and clogged fishing nets as a result of its massive aggregations in the Levantine coasts of Turkey (Öztürk and İşinibilir, 2010) causes hospital cases with severe pain. Also, Chrysaora hysoscella is another dangerous jellyfish with long tentacles and isorhiza and eurytele nematocysts (Vaissiere, 1983; Gülşahin, 2016). Rhizostoma pulmo is moderately venomous species which is not caused hospital cases (Mariottini and Pane, 2010). Erythema, burning, sneezing, rhinorrhea, urticaria can occurred by $R$. pulmo injuries. Cotylorhiza tuberculata is unharmful scyphozoan (Bernard, 1991). This species which its diameter can reach up to $40 \mathrm{~cm}$, causes feeling fear and nuisance on the swimmers when it occurred huge swarms in coastal areas (Kikinger, 1992; Bernard, 1991). Jellyfish consume zooplankton, fish eggs and larvae are in competition with fish. Also, jellyfish negatively effect on fishery and aquaculture activities (Purcell et al. 2007). Bosch-Belmar et al. (2017) showed for the first time that jellyfish blooms effected negatively aquaculture facilities in Tunisia, Italy, Spain and Malta by causing gill disorders and mortality of farmed fish and clogging net cages.

Marine ecosystems are affected by anthropogenic factors for example settlement success of polips increase related by rising on marina, port and pier constructions (Purcell et al. 2007). Tourism is one of the important sectors of Turkey. Turkey which surrounded by the Mediterranean Sea, the Aegean Sea, the Marmara Sea and the Black Sea is an important location for the distribution of both native and alien jellyfish species. The scyphozoans which distribute in Turkey coasts are Aurelia aurita, Rhizostoma pulmo, Cotylorhiza tuberculata, Phyllorhiza punctata, Rhopilema nomadica, Cassiopea andromeda, Pelagia noctiluca, Chrysaora hysoscella, Drymonema dalmatinum, Periphylla periphylla, Discomedusa lobata, Nausithoe punctata and Paraphyllina ransoni (Çınar et al., 2014; İşinibilir et al., 2015; İşinibilir and Y1lmaz, 2016). In Marmara Sea and Bosphorus Strait, Aurelia aurita blooms are seen commonly from spring to autumn (İşinibilir and Yılmaz, 2016; 2017). Also, A. aurita shows blooms in the north Aegean Sea, especially in Çanakkale, Gelibolu, Edremit Bay, and also, in İzmir Bay every year in late spring and early summer. This species forms swarms in Fethiye almost every year. These blooms can be seen even in the winter months (Gülşahin, 2017). Also, C. tuberculata occurs in large numbers in August, September and October in Gökova Bay, Muğla every year (Gülşahin and Tarkan, 2011, Gülşahin, 2017). This species showed high abundance in August and September in Güllük Bay (Öztürk et al. 2006). R. pulmo is commonly found in the western and the eastern Black Sea (İşinibilir and Yılmaz, 2017). Especially, in the eastern areas this species shows blooms in July and August every year (Gülşahin, 2017). Cassiopea andromeda which is a lessepsian species is succesfully settled in Turkey. This species is seen with high abundances in the southern Aegean Sea (Özgür and Öztürk, 2008). Also, another lessepsian species $R$. nomadica was recorded in the southern Aegean Sea and the Mediterranean coasts of Turkey (K1deyş and Gücü, 1995; Öztürk and İşinibilir, 2010; Gülşahin and Tarkan, 2011). Especially, in the Antalya, İskenderun and Mersin Bays this species forms swarms in the summer months, so the fishermen complain about to blooms of this species (Sakınan, 2011; Turan et al. 2011). In July 2009, large amount of $R$. nomadica was caught by trawl in Mersin Bay. This species composed $60 \%$ of the total catch by all fishing gears in Antalya, Mersin and İskenderun Bays in March and April 2011. The fishermen were affected these swarms of $R$. nomadica economically (Turan et al., 2011). 
This study was performed to collect data related awareness of people about jellyfish and injury cases. Since jellyfish form swarms that are usually carried around randomly by currents, it is mandatory that people be informed about jellyfish blooms and possible related injuries. This is especially important since jellyfish injury cases are generally not being recorded from hospitals and health care providers throughout Turkey. Also, this study is aimed to create awareness about the jellyfish blooms and their effects on humans on the citizen.

\section{Materials and Methods}

The questionnary was performed on 226 persons including 141 male and 85 female. The participants were holiday makers, fishermen, divers, people working in the tourism sector and local dwellers in İzmir, Kuşadası, Akyaka, Bodrum, Marmaris and Fethiye in July and August 2015. These locations are popular touristic areas, as well as fishing areas in Turkey (Figure 1).

It was asked to the participants that whether or not knew the jellyfish. Also, it was asked to the participants who contacted with jellyfish to enumerate the pain levels between 1 (very mild) and 5 (very severe). Colored pictures of the scyphozoan species which distributed in Turkey coasts were showed to the participants and were asked to show what they had seen before which of these species. Also, it was asked to the participants who knew the jellyfish that what should be done in jellyfish injury. The questionnaire form was showed in Figure 2.

\section{Results and Discussion}

Seventy eight percent of the participants declared they knew the jellyfish. Also, number of the participants have ever been in contact with a jellyfish was $74(42 \%)$ among those who know the jellyfish. This ratio was high when it was thought of holiday makers for a limited time for vacation because of their job or income levels. These people who contact with a jellyfish described these organisms soft, transparent, jelly-like and colourless. Colours of the jellyfish they meet were purple, white, blue, brown and yellowish. Thirteen persons said they saw the jellyfish with bell size $15-20$ and $20-25 \mathrm{~cm}$. only two persons have met $1-5 \mathrm{~cm}$ bell sized jellyfish. Twelve persons have given information about the tentacle length (Figure 3). Most of the participants (62\%) saw the whitish jellyfish which is thought to be $A$. aurita.

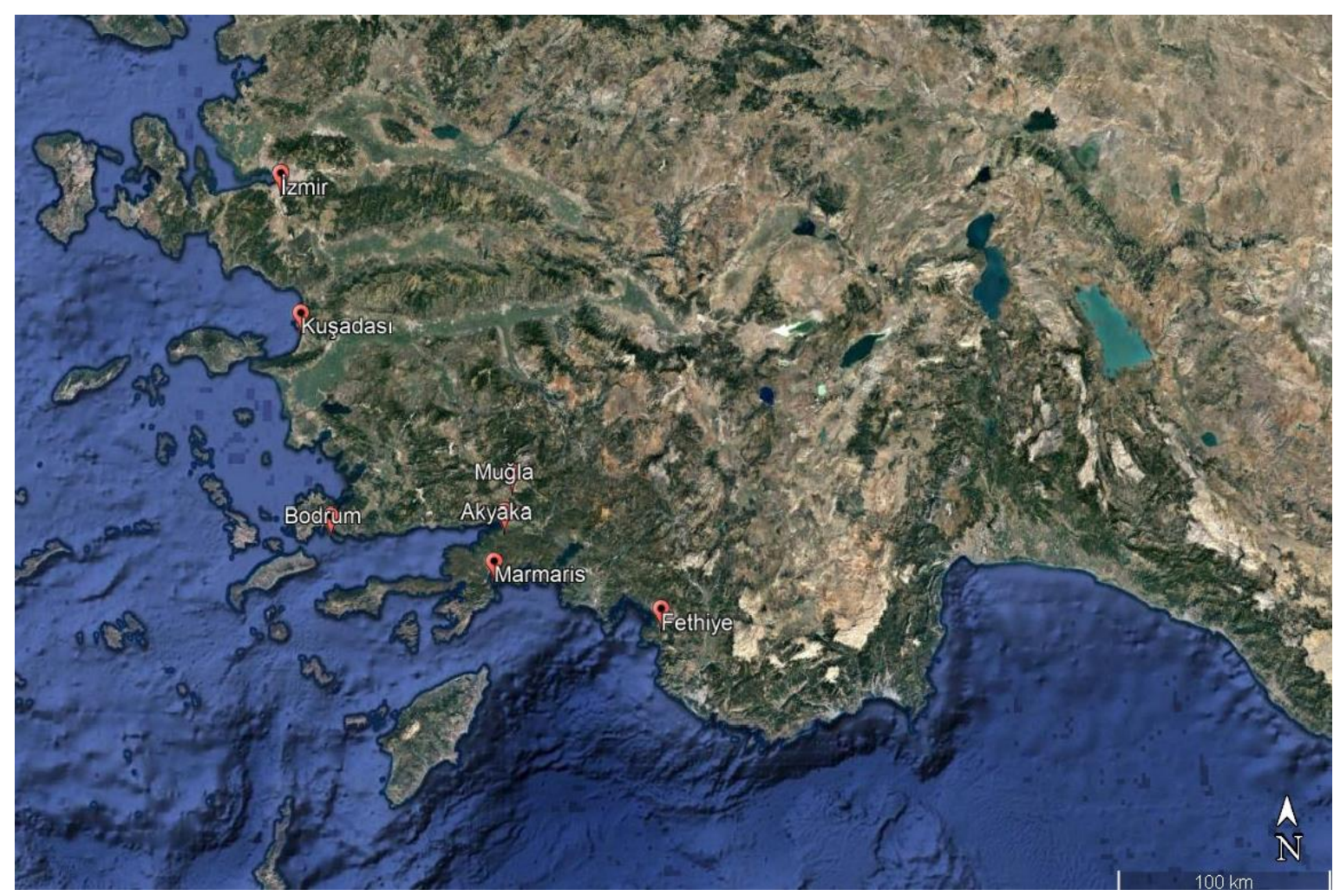

Figure 1. Study area 


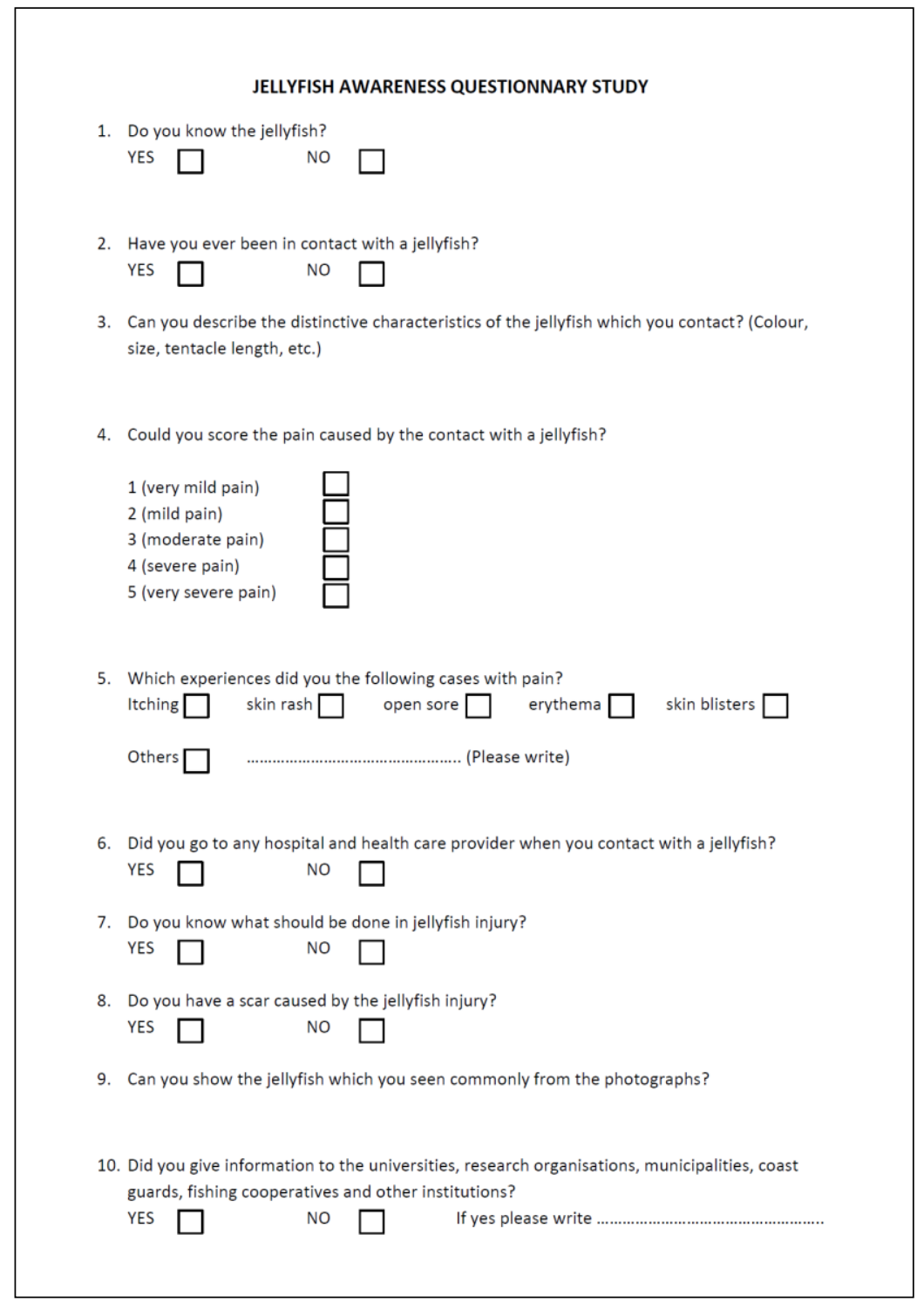

Figure 2. The questionnary form

It was wanted from the participants to show the jellyfish which they saw commonly from the photographs. A. aurita and R. pulmo were commonly seen by the participants. Also, $C$. tuberculata which form aggregations every summer in Gökova Bay was one of the most common species for the people who live in Muğla province. Other species which were seen by the several people were $C$. hysoscella, $R$. nomadica, P. noctiluca and C. andromeda (Figure 4). C. andromeda which is the first lessepsian scyphozoan species reported from the Mediterranean, lives upside-down on the sandy and muddy bottom of the sea floor (Galil et al., 1990). Therefore, this species was only observed by fishermen and divers.
Five persons declared they had no pain. Other participants determined their pain rates as shown in Figure 3. Only five persons had very severe pain because of the jellyfish injuries. Most of the participants described very mild, mild and moderate rates of pain as expected (Figure 4). In the Mediterranean Sea, jellyfish species are not as dangerous as in tropical waters (Bordehore et al., 2015; Mariottini and Pane, 2010; Mariottini et al., 2008). Therefore, jellyfish species are distributed in Turkey coasts do not lead to the hospitalization events. But, injury cases are also related to the allergic responses of the patients (Mariottini and Pane, 2010). 


\section{Description}

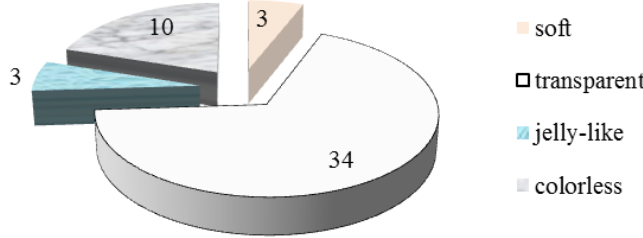

Color

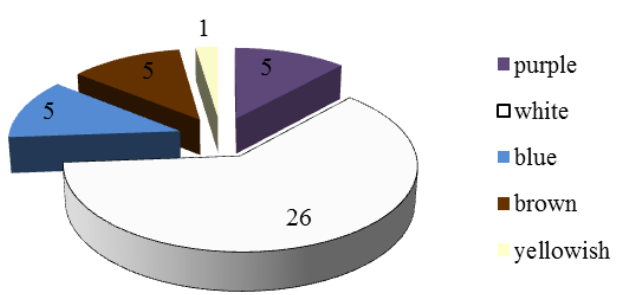

Bell size

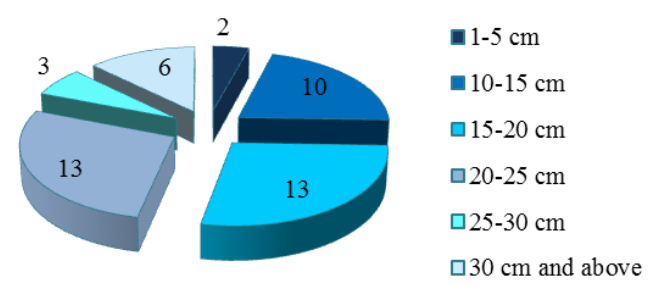

Tentacle length
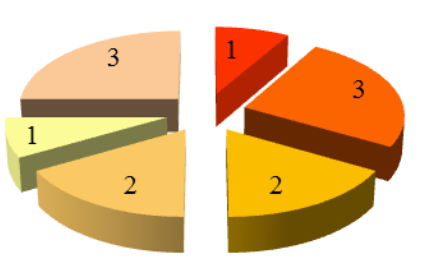

no tentacle

$=1-5 \mathrm{~cm}$

$\square 5-10 \mathrm{~cm}$

$\square 10-15 \mathrm{~cm}$

$15-20 \mathrm{~cm}$

Figure 3. Numbers of the participants who declared description, color, bell size and tentacle length of the jellyfish.

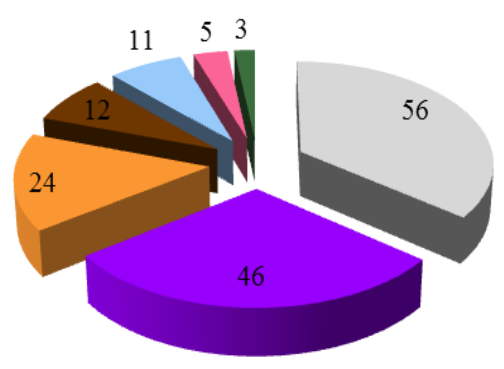

Aurelia curita

- Rhizostoma pulmo

- Cotylorhiza tuberculata

- Chrysaora hysoscella

Rhopilema nomadica

- Pelagia noctiluca

- Cassiopea andromeda

Figure 4. Common jellyfish species which were seen by the participants

Most people said they were injured by jellyfish from their legs. Localities where jellyfish injuries are most common were Bodrum (18 persons), Fethiye (15 persons) and Marmaris (15 persons). Also, thirteen persons in İzmir, eight persons in Akyaka and five persons in Kuşadası have stung by jellyfish previously.

Common effects of the jellyfish injuries were itching and erythema, according to the participants. Also, skin blisters were seen at ten persons who injured by jellyfish. Skin rash was very rare and no effect was seen on three persons (Figure 5). Only seven participants were gone to the hospital or health care provider after the injury but sixty seven persons did not need any medical treatment. The groups are the most exposed to jellyfish injuries are fishermen and swimmers.

Seventy six percent of the participants declared that they did not know what should be done about jellyfish injuries. Other participants knew that they should use vinegar or ammonia. According to Cegalon et al. (2013) ammonia inactivate the nematocysts of scyphomedusae but in cubomedusae it must be use vinegar to counteract nematocysts. Only two persons who are fisherman and divers had scars due to the jellyfish injury. They showed picture of the Pelagia noctiluca as the reason of their scars.

96 percent of the participants which encountered before jellyfish bloom or injured by jellyfish did not give an information to the universities, research organizations, municipalities, coast guards, fishing cooperatives and other institutions. Only seven persons have informed to the university and municipality in Muğla coasts. This results showed that most of the people do not cooperate with universities and 
institutes in scientific matters. Especially tourism employees avoid to inform jellyfish blooms or injury cases because they afraid of a decrease in the number of tourists. They do not have any knowledge about scientific importance and their effects on humans. Therefore, causes of blooms, effects on humans and scientific importance of jellyfish should be explained in coastal municipalities, touristic areas and diving centers. Also, trainings and seminars about what should be done in jellyfish injuries should be given.

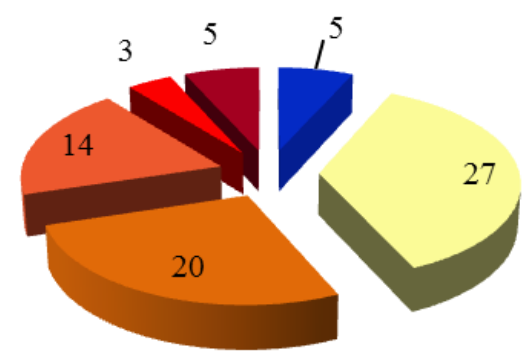

$$
\begin{aligned}
& \square \text { no pain } \\
& 1 \text { (very mild) } \\
& \square 2 \text { (mild) } \\
& \square 3 \text { (moderate) } \\
& \square 4 \text { (severe) } \\
& \square \\
& 5 \text { (very severe) }
\end{aligned}
$$

Figure 5. Pain levels of the participants who contacted with jellyfish.

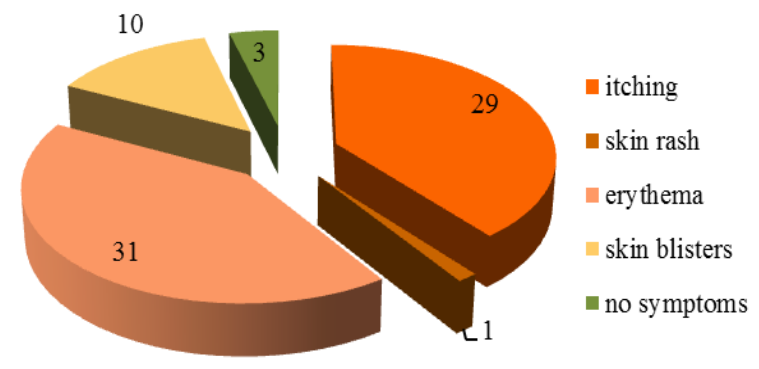

Figure 6. Symptoms on the participants caused by jellyfish

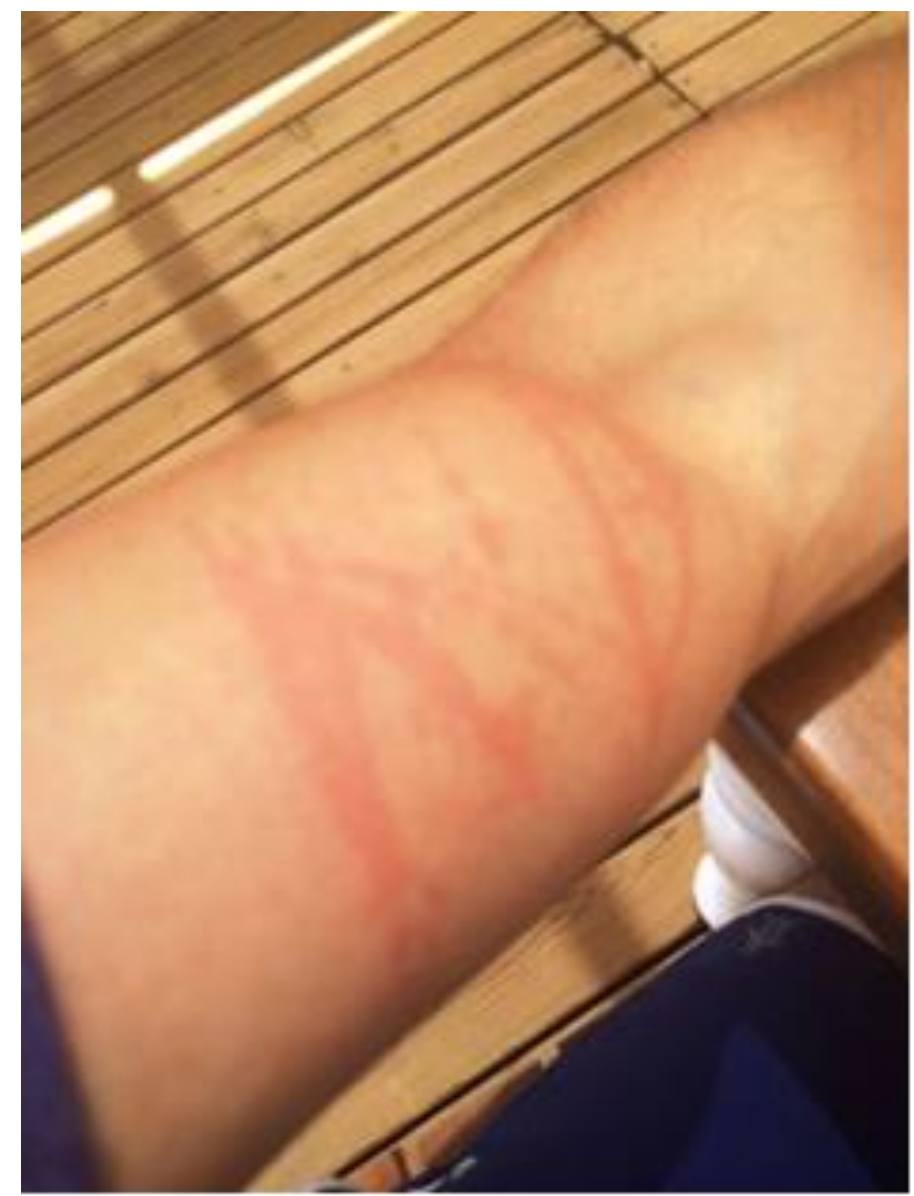

Figure 7. Scar of Pelagia noctiluca injury (Photograph by Enis Karazincir)

\section{Conclusion}

The Aegean and the Mediterranean coasts of Turkey are important tourism areas. Increasing tourism constructions may cause rising jellyfish blooms in these areas (Purcell et al., 2007; Richardson et al., 2009; Duarte et al., 2013). Therefore, it is inevitable that the tourism sector in collaboration with universities and institutes. The persons working in tourism sector must be conscious about need to do in jellyfish injuries.

Nevertheless, scientific point of view of people has not developed in Turkey. In the past, it was contacted with many hotels about informing jellyfish blooms in all the Muğla coasts but did not get any feedback. For this reason, this study is important to create awareness about scientific researches on people. With this study, forty nine persons of the participants who do not know the jellyfish were informed about these organisms. It was told to all of the par- 


\section{Journal of Aquaculture Engineering and Fisheries Research, 4(1), 55-63 (2018)}

Journal abbreviation: J Aquacult Eng Fish Res

ticipants what need to do in jellyfish injuries. And also, importance of the scientific collaborations with universities and research institutes was explained to the people.

Knowledge exchange between people and scientist can solve the problems of each side. To this end, the National Jellyfish and Gelatinous Organisms Watch Programme (http://www.yayakarsa.org/index.php/en/) was started in 2014 in conjunction with the CIESM Jellywatch Programme.

Jellyfish blooms cause nuisance on people even is not dangerous. Most of the participants defined the jellyfish as disgusting, irritating, burning and sticky. Jellyfish stings injure the bathers with pain and other influences such as itching, erythema, oedema, blisters etc. Sometimes people who injured by jellyfish need medical treatment. But, jellyfish injury cases are generally not being recorded from hospitals and health care providers throughout Turkey. Also, there are not lifeguards and medical centres in all the beaches in our coasts. Therefore, the actual number of jellyfish injuries is unknown. For this reason, further projects and questionnaires should be performed to collect data about jellyfish injuries. Additionally, trainings should be given in schools, tourism enterprises and diving schools to create awareness to inform jellyfish blooms and injuries.

\section{References}

Bernard, P. (1991). Recapitulation des résultats de la surveillance des proliférations de méduses sur les côtes méditerranéennes françaises durant l'été 1987. UNEP: Jellyfish blooms in the Mediterranean Proceedings of the II Workshop on Jellyfish in the Mediterranean Sea MAP Tech. Rep. Ser., No 47; UNEP: Athens, Greece, 1991; pp. 51-57.

Bordehore, C., Fuentes, V.L., Atienza, D., Barberá, C., Fernandez-Jover, D., Roig, M., Acaveda-Dodley, M.J., Canepa, A.J., Gili, J.M. (2011). Detection of an unusual presence of the cubozoan Carybdea marsupialis at shallow beaches located near Denia, Spain (south-western Mediterranean). Marine Biodiversity Records, 4.

Bordehore, C., Fuentes, V.L., Segarra, J.G., Acevedo, M., Canepa, A., Raventós, J. (2015). Use of an Inverse Method for Time Series to Estimate the Dynamics of and Management Strategies for the Box Jellyfish Carybdea marsupialis. PLoS ONE, 10(9), e0137272.

Bosch-Belmar, M., Azzurro, E., Pulis, K., Milisenda, G.,
Fuentes, V., Yahia, O. K. D., Micallef, A., Deidun, A., Piraino, S. (2017). Jellyfish blooms perception in Mediterranean finfish aquaculture. Marine Policy, 76, 1-7.

Burnett J.W. (2001) Medical aspects of jellyfish envenomation: pathogenesis, case reporting and therapy. $\mathrm{Hy}$ drobiologia 451, 1-9.

Carli, A., Cotta, S., Mariottini, G.L., Pane, L. (1991). Considerazioni sulla proliferazione di Cnidari planctonici nel Mar Ligure. Meditravel 1991, 0, 112-120.

Carli, A., Mariottini, G.L., Pane, L. (1995). Ecological and medical aspects of jellyfish poisoning. In Epidemiological studies related to the environmental quality criteria for bathing waters, shellfish-growing waters and edible marine organisms MAP Tech. Rep. Ser. 1995, No 93; UNEP: Athens, Greece, 1995; pp. 1-21.

Çınar, M.E., Yokeş, M.B., Açık, Ş., Bakır, A.K., (2014). Check-List of Cnidaria and Ctenophora from the Coasts of Turkey. Turkish Journal of Zoology 38, 677697.

Duarte, C.M., Pitt, K.A., Lucas, C.H., Purcell, J.E., Uye, S.i., Robinson, K., Brotz, L., Decker, M.B., Sutherland, K.R., Malej, A., Madin, L., Mianzan, H., Gili, J.-M., Fuentes, V., Atienza, D., Pagés, F., Breitburg, D., Malek, J., Graham, W.M., Condon, R.H. (2013). Is global ocean sprawl a cause of jellyfish blooms?. Frontiers in Ecology and the Environment, 11, 91-97.

Fenner, P.J. (1998). Dangers in the ocean: the traveler and marine envenomation. I. Jellyfish. Journal of Travel Medicine, 5(3), 135.

Galil, B.S., Spanier, E., Ferguson, W.W. (1990). The Scyphomedusae of the Mediterranean Coast of Israel, Including two Lessepsian Migrants new to the Mediterranean. Zoologische Mededelingen Leiden, 64(7), 95105.

Gershwin, L.A. (2013). Stung!: On jellyfish blooms and the future of the ocean. University of Chicago Press, ISBN 13: 978-0-226-02024-2

Gordoa, A., Acuña, J.L., Farrés, R., Bacher, K. (2013). Burst feeding of Pelagia noctiluca ephyrae on Atlantic bluefin tuna (Thunnus thynnus) eggs. PloS ONE, 8(9), e74721. 
Gülşahin, N., Tarkan, A. N. (2011). The first confirmed record of the alien jellyfish Rhopilema nomadica Galil, 1990 from the southern Aegean coast of Turkey. Aquatic Invasions, 6(Suppl 1), S95-S97.

Gülşahin, N. (2016). Nematocyst types of Chrysaora hysoscella (Linnaeus, 1766) from Turkey. 5th International Jellyfish Bloom Symposium, May 30- June 3, 2016, Barcelona, Spain, p.166.

Gülşahin, N. (2017). Jellyfish Blooms and Injuries in Turkey. In Gian Luigi Mariottini, Ed. Jellyfish: Ecology, Distribution Patterns and Human Interactions (p.149162). Nova Science Publishers, ISBN 978-163-485-6881

Isinibilir, M., Y1lmaz, I., Demirel, N., (2015). New records of jellyfish species in the Marmara Sea. Italian Journal of Zoology, 82, 425-429.

Isinibilir, M., Y1lmaz, N.İ. (2016). Jellyfish Species in the Sea of Marmara, in: Özsuy, E., Çağatay, M.N., Balkıs, N., Balkıs, N., Öztürk, B. (Eds.), The Sea of Marmara; Marine Biodiversity, Fisheries, Conversation and Governance. Turkish Marine Research Foundation, İstanbul. ISBN 978-975-8825-34-9

Isinibilir, M., Yılmaz, İ.N., (2017). Jellyfish dynamics and their socioeconomic and ecological consequences in Turkish Seas, in: G.L., M. (Ed.), Jellyfish: Ecology, Distribution Patterns and Human Interactions. Nova Publishers, New York, pp. 51-70. ISBN 978-163-48568-81

Kideys, A.E., Gücü, A.C. (1995). Rhopilema nomadica: a Lessepsian scyphomedusan new to the Mediterranean coast of Turkey. Israel Journal of zoology, 41(4), 615617.

Kikinger, R. (1992). Cotylorhiza tuberculata (Cnidaria: Scyphozoa)-Life history of a stationary population. PSZNI Mar. Ecol. 1992, 13, 333-362.

Kokelj, F., Burnett, J.W. (1988). Reazioni inusuali indotte dal contatto con la medusa Pelagia noctiluca. Giornale Italiano di Dermatologia e Venereologia, 123, 501503.

Kokelj F., Del Negro P., Montanari G. (1992) Jellyfish dermatitis due to Carybdea marsupialis. Contact Dermatitis, 27, 195.
Labadie, M., Aldabe, B., Ong, N., Joncquiert-Latarjet, A., Groult, V., Poulard, A., Coudreuse, M., Cordier, L., Rolland, P., Chanseau, P., de Haro, L. (2012). Portuguese man-of-war (Physalia physalis) envenomation on the Aquitaine Coast of France: An emerging health risk. Clinical toxicology, 50(7), 567-570.

Larson R.J. (1976). Cubomedusae: feeding-functional morphology, behaviour and phylogenetic position. In Mackie G.O. (ed.) Coelenterate ecology and behavior. New York: Plenum Publishing Co., pp. 237-245. ISBN 978-1-4757-9724-4_25

Lin, D.C., Hessinger, D.A. (1979). Possible involvement of red cell membrane proteins in the haemolytic action of Portuguese Man-of-War toxin. Biochemical and Biophysical Research Communications, 91(3), 761-769.

Mariottini, G.L., Giacco, E., Pane, L. (2008). The Mauve Stinger Pelagia noctiluca (Forsskål, 1775). Distribution, Ecology, Toxicity and Epidemiology of Stings. A Review. Marine Drugs, 6(3), 496-513.

Mariottini, G.L., Pane, L. (2010). Mediterranean jellyfish venoms: A review on scyphomedusae. Marine Drugs, 8(4), 1122-1152.

Milla L., Segura-Puertas L., Celis L. (2000). Dermatitis por contacto con Carybdea marsupialis (Cnidaria Cubozoa). Dermatologi'a Revista Mexicana 44, 167-170.

Nogueira Jr M., Haddad M.A. (2008). The diet of Cubomedusae (Cnidaria, Cubozoa) in southern Brazil. Brazilian Journal of Oceanography, 56, 157-164.

Özgür, E., Öztürk, B. (2008). A population of the alien jellyfish, Cassiopea andromeda (Forsskål, 1775) [Cnidaria: Scyphozoa: Rhizostomea] in the Ölüdeniz Lagoon, Turkey. Aquatic Invasions, 3(4), 423-428.

Öztürk, B., Ünsal, N., Şener, E., Altuğ, G., Aktan, Y., Güven, E., Topaloğlu, B., Keskin, Ç., İşinibilir, M., Çardak, M., Eryalçın, K.M., Çiftçi, P.S. (2006). Muğla İlinde $\mathrm{Su}$ Ürünleri Yetiştiriciliği Açısından Hassas Alanlar ile Yeni Yetiştiricilik Alanlarının Belirlenerek Kirlenme Parametrelerinin İzlenmesi Projesi, İstanbul Üniversitesi Su Ürünleri Fakültesi, 1. Rapor, 2006. 
Öztürk, B., İşinibilir, M. (2010). An alien jellyfish Rhopilema nomadica and its impacts to the Eastern Mediterranean part of Turkey. Journal of Black Sea/Mediterranean Environment, 16(2), 149-156.

Purcell, J.E., Uye, S.I., Lo, W.T. (2007). Anthropogenic causes of jellyfish blooms and their direct consequences for humans: a review. Marine Ecology Progress Series, 350, 153-174.

Richardson, A.J., Bakun, A., Hays, G.C., Gibbons, M.J. (2009). The jellyfish joyride: causes, consequences and management responses to a more gelatinous future. Trends in Ecology and Evolution, 24(6), 312-322.

Sakinan, S. (2011). Recent Occurrence of Indopacific Jellyfish Rhopilema nomadica in North-Eastern Levantine Sea. First International Workshop on Jellyfish and Other Gelatinous Species in Turkish Marine Waters, 20-21 May 2011, Bodrum, Muğla, Turkey, p. 58-65.

Sa'nchez-Rodri'guez J., Torrens E., Segura-Puertas L. (2006). Partial purification and characterization of a novel neurotoxin and three cytolysins from box jellyfish (Carybdea marsupialis) nematocyst venom. Archives of Toxicology, 80, 163-168.
Scarpa, C. (1984). On skin injuries provoked by Coelenterata and Echinodermata. UNEP: Workshop on Jellyfish Blooms in the Mediterranean, Athens, Greece, 31 October-4 November 1983; UNEP: Athens, Greece, 1984; pp. 95-97.

Turan, C., Özbalcılar B., Ergüden, D., Uygur, N. (2011). Occurrence and Abundance of Lessepsian Jellyfish Cassiopea Andromeda (Forsskal, 1775) in Iskenderun Bay, the Northeastern Mediterranean Sea. First International Workshop on Jellyfish and Other Gelatinous Species in Turkish Marine Waters, 20-21 May 2011, Bodrum, Muğla, Turkey, p. 73-77.

UNEP (1984). Workshop on Jellyfish Blooms in the Mediterranean, Athens, Greece, 31 October - 4 November 1983; UNEP: Athens, Greece, 1984.

Vaissiere, R. (1983). Sur quelques travaux relatifs aux méduses acalèphes de Méditerranée. Workshop on Jellyfish Blooms in the Mediterranean, Athens, Greece, 31 October - 4 November 1983; UNEP: Athens, Greece; pp. 149-161.

http://www.yayakarsa.org/index.php/en/ (accessed 10.04.17) 